\title{
失語症
}

\author{
大 柣 美 佳*
}

要旨：失語症を理解するには，脳を音素・音韻に関する領域（phonetic \& phonemic area）と, 内 容・語と語の関係に関する領域（content \& context area）の二大機能系に分けて考えるとわかりや すく, この機能系とその解剖学的基盤を基本的視点として提示した。

また，失語症を分類するには質的な評価が必要であり，これを重症度や経時的変動の評価に適し ている量的尺度と使い分けることが妥当であること，さらに発語の分類は流暢・非流暢ではなく， 失構音の有無で判断するのが有用であること, 復唱能力の判断に苦慮した場合には音韻性錯語の有 無，言語性短期記憶障害の有無を援用することが有用であることを指摘した。

次に, 言語の要素的症状の局在地図と, 古典的失語型との関係を概説し, 未解決問題として, 超 皮質性運動失語の位置づけ，皮質下性失語の特徵，文レベルの障害について考察した。

最後に，言語機能に影響を与える非言語的背景について検討した。まず，意図性と自動性の解離 について, ウェルニッケ失語患者における復唱能力が, あえて復唱を意識しない場合のほうが良好 であることを示した。次に, 呼称課題について, 最初の語が出やすいことも定量的に示した。これ は, とくに側頭葉に病巣が及んでいる患者で明らかであり, 病巣による違いも考慮すべきことが推 測された。最後に, 呼称課題を行う際に, 右半球に負荷がかかるような課題と交互に施行すると呼 称の成績が改善した 1 例を報告した。以上より，失語症に対峙する場合，非言語性の要因も考慮す ることが重要であることを指摘した。

(高次脳機能研究 29 (2)：194 205, 2009)

Key Words：失語症分類, 機能局在, 要素的症状, 非言語性背景, 意図性と自動性

Classification of aphasia, Localization of language function, Elementary impairment of language, Non linguistic back ground, Automatico-voluntary dissociation

はじめに

失語症の理解に特別の職人技は必要ではない。 なぜなら，失語症の診断は誰でも同じ結論に至る べき普遍的原理に則ってなされるべきものだから である。本稿では，実際の臨床に即した失語症の 理解のポイントと, 問題点へのアプローチを試み る。

\section{I．失語症患者を理解するための ポイント}

\section{1. 脳の機能・構造の概略}

失語症は脳の器質的な損傷により出現する。し たがって, 失語症と対峙する時, 脳の大まかな機
能系を念頭におくべきである。図 1 (A) は従来示 されてきた言語機能系を二分する解剖学的基盤で ある（Benson 1979）。シルビウス裂周囲は ‘環シ ルビウス裂, と称され，この部位の損傷でシルビ ウス溝周辺失語症候群（ブローカ失語, 伝導失語, ウェルニッケ失語，および失語という用語を冠す ベきかの議論はあるが，純粋語唖，純粋語壟も含 まれる）が出現する。一方，この領域を取り囲む さらに外側は ‘環・環シルビウス裂”と称され, この部位の損傷で境界域失語症候群（超皮質性感 覚失語，超皮質性運動失語，健忘失語）が出現す る。この二大領域は, 今日の画像知見とあわせる と若干の訂正が必要である（図1 (B))。シルビウ 又裂周囲は音素，音韻に関する領域（phonetic \& 


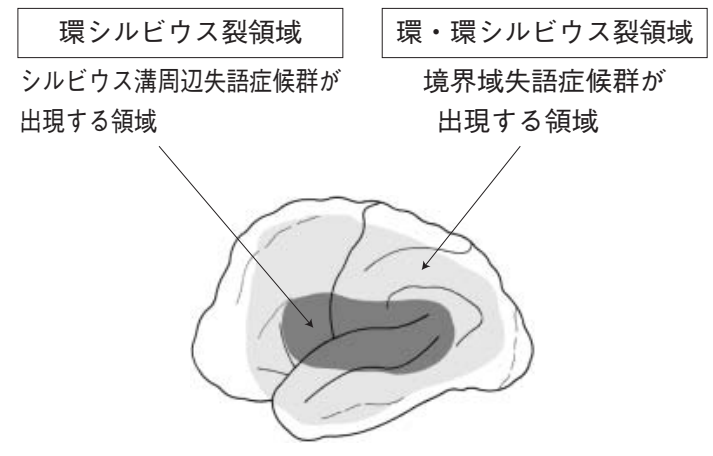

図1（A）言語に関する脳の機能系 (Benson, D. F. 1979より引用)

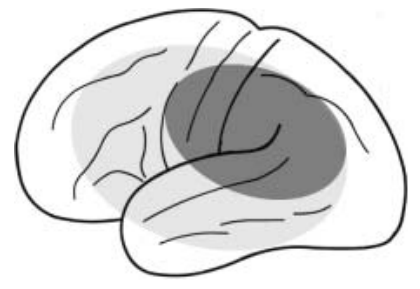

構音と音韻（音素）

Phonetic \& Phonemic area

・アナルトリー

・音韻性錯語

内容と関係

Context \& Content area

- 意味理解障害・文の処理障害

・喚語障害・・経時的処理障害

図1（B）

phonemic area）と考えられる。なぜならば，この 部位には失構音（アナルトリー, 発語失行) 注1) の 責任病巣である中心前回（Lecoursら 1976， Tonkonogy 河村ら 1990，松田ら 2005，大槻 2005a，杉下 1994），音韻性錯語の責任病巣である縁上回～弓上 束（Green ら 1977，相馬 1986，1992，1997，大 梘 1999a，2008c）が含まれているからである。一 方，その前方外側の部位は環・環シルビウス裂領 域に相当し，この部位の損傷では“音’の問題は 出現しないが, 意味理解障害, 喚語障害, また経 時的な言語処理，すなわち文の処理に問題が生じ
る。この部位は語の内容と, 語と語の関係に関す る部位（content \& context area）と考えられる。

\section{2. 量的評価と質的評価}

失語型の分類は質的評価でなされるべきである。 質的評価とは，ある症候が認められるか否かで判 断する方法である。たとえば, 患者の発語に失構 音があるか否か，音韻性錯語があるか否か，単語 レベルの理解障害があるか否か....などで判断する。 これは検査で何点というような量的評価とは異な る。数值になりにくいことから, 非客観的である と誤解されやすいが, 質的評価は, 明確な定義を もって判断すれば，普遍的で客観的な尺度たりう る。むしろ, 量的尺度 (点数) は, 重症度を示す ことはできても，障害の本質を示すことはできな いし，また，どこに境界線を引くかで常に議論が 存在する。量的尺度は重症度の指標や改善度の尺 度として，一方，質的尺度は障害の本質を示すの に有用であり，使い分けるのが妥当である。

\section{3. 失語型分類に関する議論の歯切れを悪くし ている原因と対策}

失語症がわかりにくいとされる理由のひとつに, 失語型の分類に明確な定義がないことが挙げられ る。また必須所見（その失語型に分類するために 必須の所見), 容認所見 (その失語型に分類するの に出現しても差しつかえない所見）と除外所見 (その所見があるとその失語型とは言い難くなる所 見）が明確に区別されていない。これらが明確で ないと，失語型分類に困難を生じる。

1）流暢・非流暢は明確な境界線を引く定義がな い

必須所見, 容認所見, 除外所見がもっとも曖昧 な事項のひとつに, “流暢” “非流暢” の判断があ る。これは失語症分類でもっとも初歩的判断と考 えられているが，実際の臨床場面で判断に苦慮す る場合も少なくない。これは, 今日のような画像 診断方法がなかった時代に, 病巣部位をおおまか に知るひとつの方法として, 提起された基準にそ の原型がある（Goodglassら 1964，Benson 1967）。 Benson（1967）の提示した10項目（図1 (C)）の うち, すべて左側の項目, たとえば発話量が 1 分

注 1）:この現象に関しては, 失構音, アナルトリー, 発語失行などの用語があるが, 現象としてほぼ同じ現象を指すものとして本稿では失 構音と表現する（詳細は，大梘 2005a）。 


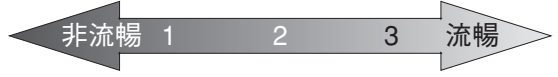

発語量（1 分間の語数） 50 以下……………………50以上

プロソディー

発音（構音）

句の長さ（比率）

努力性（開始）

発話間の休止時間

発語衝迫の有無

保続

語選択

錯語

異常

正常

異常

正常

低 …………………高

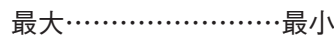

頻回………時に………稀

- ……少々 $. . \cdots \cdots+$

頻回……... あり......... 稀

実詞中心………………文法的な

なし……時に……頻回

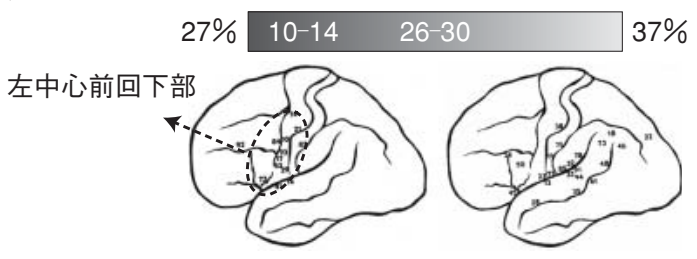

図1（C） Benson（1967）の10項目

(Benson, D. F. 1967より引用)

間に 50 以下，プロソディー異常があり，構音の異 常もあるという具合に, 左側の項目に該当する所 見が並ぶ場合には，容易に“非流暢”と判断でき， 一方，右側の項目に該当する所見が並ぶ場合には “流暢” と判断できる。しかし，実際の患者の発語 はそう単純ではない。発語量は多いのに構音に異 常があったり，逆に，発語量は少なく，句も短く ても，構音もプロソディーも問題ない場合もある。 このように，該当する項目が左右に分散すること も珍しくない。該当項目が分散した場合に，どの 項目を ‘要” として判断すべきかの基準が必要で ある。実は，この“要”が何なのかはすでに Bensonの論文（1967）のなかにヒントがある。こ の論文で，左列に該当する項目が多い患者の病巣 は図 1 (C) 下左側に示され, 右列に該当する項目 が多い患者の病巣は図1（C) 下右側に示されてい る。前者は左中心前回がもっとも関与しているこ とを示している。左中心前回は今日の視点でみる と, 失構音の責任病巣である。したがって，10 項 目中の ‘要’ は, 失構音と考えるのが妥当であり, 10 項目を全部引き合いに出すまでもなく, 失構音 の有無で発語を判断するのが，簡にして要を得る。

2）復唱は良好・不良の二分で片付けられない 復唱の良否も基準が明示されていない。単語も
復唱できないほど重度の障害であれば，容易に “復唱不良”と判断でき，長文も復唱できれば “復 唱良好’ と判断できる。一般に 5 〜 語以上の文 が復唱できれば復唱良好とされている（山鳥 1985）。しかし，臨床で問題になるのは，その中間 に位置する場合である。たとえば，何度も修正を 繰り返し，最終的には復唱できた場合，まったく 正常に復唱できた場合と同じく ‘復唱良好’ と判 断すべきなのか，あるいは，その時によって5〜 6 語文の復唱ができたりできなかったりする場合 にはどう判断するのかなど，実際の臨床ではさま ざまな問題がある。実際，WAB 失語症検査（杉下 1986）に記載されている失語症の分類基準では, 復唱不良とされているウェルニッケ失語で, 復唱 の点数は 10 点満点の $0 \sim 8.9$, 一方, 復唱良好と されている健忘失語では 7 〜 10 となってる。健 忘失語で 7 点の場合もあれば，ウェルニッケ失語 で 8.9 点の場合もあるということになる。このこ とは，点数のみで失語型を分類できないことをも 示している。この分類では伝導失語は含まれてい ない。

それでは，何を手がかりにしたらよいのか。ま ず，「復唱」を失語型分類の拠り所にする理由・意 義に立ち返る。復唱能力が低下するには大きく 2 つの原因がある。1つは，聴覚的に入力された音 声情報を把持する能力の低下，すなわち言語性短 期記憶の低下である。もう1つは，発語の問題， たとえば，頻発する音韻性錯語のために，言い直 しを繰り返し，成功しない場合である。復唱能力 を評価するということは，間接的にそれらの能力 を評価していることになる。したがって，復唱能 力の判断に苦慮した場合には，この 2 大能力を直 接評価するとわかりやすい。

i）言語性短期記憶

短期記憶の詳細はここでは論じないが（他稿参 照：大槻ら 1999a)，記憶は長期記憶と短期記憶に 分類され，言語性短期記憶は後者のうち，言語を 素材とした記憶をさす。“短期’ は数秒〜分の単位 である。日常で，たとえば「人からきいた電話番 号を繰り返して言う」類の記憶である。これは長 期記憶とは異なる神経機構によって営まれている 記憶系であるため，分けられている。一般には， 
数唱が簡便な評価方法として用いられている。な ぜならば，数字は言語情報でありながら，数字列 には意味の関与が少ないため, 純粋な音韻把持能 力として近似できると考えられるからである。た だし，発語の問題（失構音や音韻性錯語）のため, 正しく数字列を表出できない場合には, 順に数字 を指差す方法で評価する。言語性短期記憶は Baddeleyら（1974）のワーキングメモリの理論で, 音韻性ループに相当する。言語性短期記憶の解剖 学的基盤は左頭頂葉，とくに縁上回という報告が 多い (Warrington ら 1971, Saffran ら 1975, McCarthy 5 1984, Della Sala ら 1993, Vallar ら 1995, Sakurai ら 1998, 櫻井 2001) が, 左シルビ ウス裂を囲む部位，すなわち上側頭回〜縁上回〜 中心前回までの領域（およびそれらの皮質下）の どこが損傷されてもこの障害は出現する（相馬 1992)。

\section{ii）音韻性錯語}

音韻性錯語は有用な局在徵候である（大槻ら 1999b，大槻 2003)。なぜならば，1つにはさまざ まな錯語のなかでも，唯一責任病巣が明らかであ ること，2つめには，語性錯語などは全般の意識 状態の低下でも出現しうるが，音韻性錯語は言語 レベルの障害であり，意識状態の低下や全般的知 的機能低下ではほとんど出現しない点で特異性が あるからである。失構音を伴わない音韻性錯語は 左縁上回を中心として，左上側頭回〜縁上回〜中 心後回（およびこれらの皮質下）のどこが損傷さ れても出現する注2)。これらより前でも後ろでも音 韻性錯語は出現しない。したがって，音韻性錯語 の出現は, 前述した境界域失語症候群（超皮質性 失語）にとって除外所見となる。また，中心前回 損傷では失構音が出現し, 現象としては音韻性錯 語が出現する。しかし，この場合の音韻性錯語が, 失構音のために音が歪んで別の音に近くなって出 現したものなのか, 側頭葉〜頭頂葉損傷による失 構音のない音韻性錯語と同じ性質のものなのかは 明らかではない（したがって，音韻性錯語が出現 する部位のうち，中心前回以外の部位を “失構音 を伴わない音韻性錯語’が出現する部位と表現し
ておく)。

上述のように，復唱能力を評価することの意義 は, i）言語性短期記憶, ii）音韻性錯語の評価に 裏打ちされる。復唱能力の判断に苦慮する場合に は, 言語性短期記憶障害, 音韻性錯語の有無を代 替基準として援用するとわかりやすい。

\section{4. 要素的言語症状の局在地図}

要素的言語症状を出現させる局在部位と古典的 失語型の関係を図示した（図 $2(\mathrm{~A}) \sim(\mathrm{C}),(大$ 柣 2007a，2008a，2008b，2008d）を参照)。“要” は 4 つの所見である。失構音, 音韻性錯語, 単語 の理解障害 (単語 pointing 障害), 喚語障害 (呼称 障害, 語列挙障害) である。また, 破線で示した (図 2 (B)）のは，言語性短期記憶を担う神経基盤 である。これらを念頭におくと, 要の 4 所見の判 断で, 古典的失語型分類は明確に分類でき, しか も, 分類することによってどの機能系に問題が生 じているかを理解することができる。代表的な失 語型の必須症状を図 2 (D) にまとめた。

\section{II. 未解決問題へのアプローチ}

\section{1. 超皮質性運動失語の位置づけ}

補足運動野失語（図 $2(\mathrm{C}))$ は, 左前頭葉内側 面損傷による言語障害である。失語という用語が 適切かの議論は別として,「自発語が減少し, 語の 列挙がきわめて不良だが, 復唱や視覚性呼称（物 品呼称) は良好で, 発語にも構音やプロソディー の問題はない」ことが特徴である。良好な復唱能 力と低下した自発語の対比から, 古典的分類で超 皮質性運動失語に相当する。病巣が明らかなので, 病巣の名を冠した補足運動野失語の名称が今日汎 用されている (Benson 1993)。

超皮質性運動失語は上記の補足運動野失語が注 目される前から言及されていた失語型である。し かし, その症候の定義は他の失語型に比較して広 い。山鳥（1985）は超皮質性運動失語について 「〜細かくみれば亚型はもっと多く存在する可能性 が高い。その意味で復唱と自発語の解離のみに焦 点を絞り，それ以外の諸特徴は一応無視した上で, そこにはめこまれる失語症候群をすべて超皮質性

注 2)：この部位は言語性短期記憶障害の責任病巣とほぼ一致している。すなわち, 言語性短期記憶障害と音韻性錯語は相伴って出現するこ とがほとんどである。しかし，両者の回復には解離があり，また，純粋な言語性短期記憶障害を呈した例の報告もまれながらあり (水田 1999), 言語性短期記憶障害と音韻性錯語はその責任病巣がきわめて近接している異なる症候と考えるのが妥当であろう。 
$6(198)$

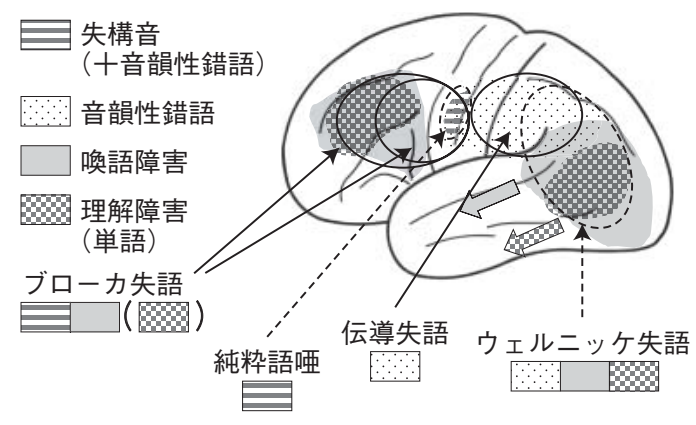

図2（A）要素的症状と古典的失語型の関係

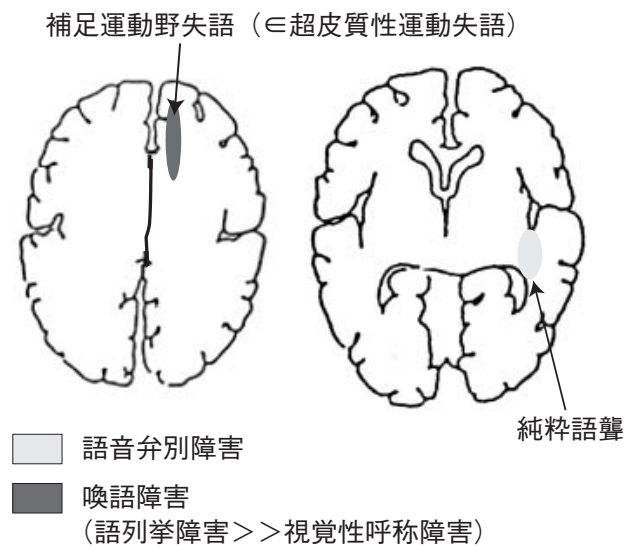

図2 (C)

運動失語と呼ぶ立場を本書はとる」としている。 広い定義のため, 補足運動野失語も超皮質性運動 失語に分類されることに矛盾はないが, 補足運動 野以外の病巣でも出現するともいえる。補足運動 野以外の超皮質性運動失語の責任病巣は左（下） 〜中前頭回を中心とした部位である（Rubens 1976, Freedman 1984, 榎戸 1985, 榎戸ら 1988, Alexanderら 1989)。この部位は昨今報告が多い前 頭葉損傷による超皮質性感覚失語（佐藤ら 1991， 濱中ら 1992, 大㭇ら 1994, Otsuki ら 1998）の出 現部位とほぼ同じである（図2（B））。補足運動野 以外の超皮質性運動失語の責任病巣と, 前頭葉損 傷による超皮質性感覚失語の責任病巣がほぼ同じ であることをどう解釈するか，未解決問題である。 ここで, 超皮質性感覚失語と超皮質性運動失語を すべて明確に区分できる定義がないことを指摘し たい。発語面では, 超皮質性運動失語では・自発 語の低下”が特徵とされているが，超皮質性感覚
高次脳機能研究 第 29 巻第 2 号

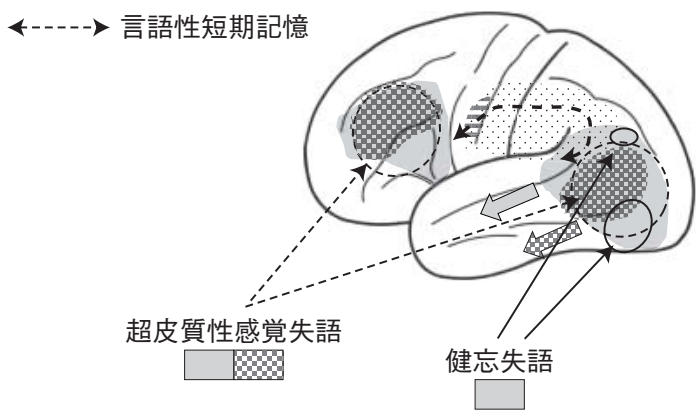

図2(B)

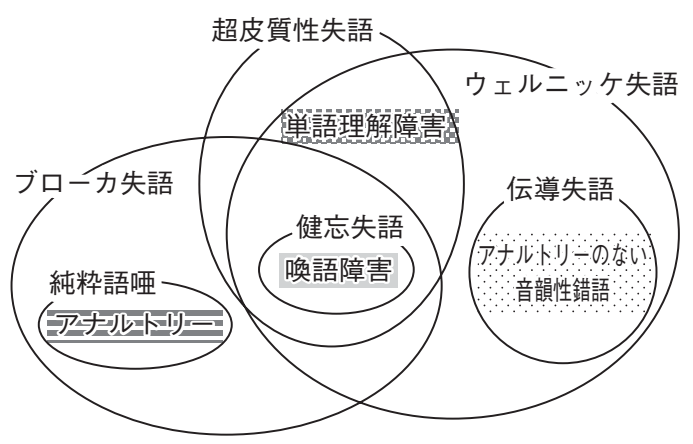

図2（D） 必須所見と古典的失語型の関係

失語ではとくに言及はない。失構音や音韻性錯語 に関しては，超皮質性感覚失語では出現しないが， 超皮質性運動失語でもその有無はとくに規定され てはいない。理解では, 超皮質性感覚失語は単語 レベルから障害があるが, 超皮質性運動失語では 理解障害は“概ね”良好とされてはいるが，“概ね” の内容は定義がない。また，超皮質性運動失語の 理解障害はその病巣の広がりに依存するとの見解 もあり（大柣ら 1995）, 理解障害の有無や程度は 超皮質性運動失語分類の本質に関与しないと推測 される。以上より, 超皮質性感覚失語と超皮質性 運動失語の症候の相違は, “自発話の減少”の有無 のみとなる。自発語の減少は重度であれば容易に 判断可能であるが，基準がないので境界に線引き ができない。超皮質性感覚失語でも自発話が少な めの患者もいる。どの程度自発話が少ないと超皮 質性運動失語に分類すべきなのか不明であり，し たがって, 判断者によって超皮質性運動失語とす 
るか, 超皮質性感覚失語とするか, 異なる可能性 さえある。このように ‘自発話の減少”という曖 昧な事項で，あえて“分類”する意義は現時点で はないのかもしれない。むしろ，両者とも phonetic \& phonemic areaが保たれている失語型という共 通点があり, 病巣の違いも現時点で明らかでない ことより，その共通点で大きく括ってしまうこと に不都合はないように思われる。したがって，超 皮質性失語は，(1)前頭葉損傷による超皮質性失語 （超皮質性感覚失語と超皮質性運動失語を含む）, (2)補足運動野損傷による補足運動野失語（超皮質 性運動失語), (3従来の後方領域損傷による超皮質 性感覚失語の 3 型で分類するのがわかりやすく, 説明可能な範囲と考える。

\section{2. 皮質下性失語の特徴}

皮質下性失語とは，大脳皮質より下に存在する 神経核の損傷で出現する失語型で, 視床失語, 線 条体失語などの失語型の総称である。臨床で, ‘皮 質下’ という用語は白質を表す場合もあるが (例：皮質下性出血)，これとは用法が違うので注 意が必要である。被殼や視床の梗塞・出血は頻度 が高いが，左被殼や左視床の損傷で失語症が必ず しも出現するわけではない。このことから，これ らの部位が言語機能に直接関わっているのではな く，大脳皮質の言語関連領域が間接的に影響を受 けて, 失語症状が出現しているのではないかとい う解釈もある。しかし大脳皮質で血流低下の所見 がなくても失語症が出現することもあり，この問 題は未解決である。ただ，いずれにしても，ひと つ明確な事実は，皮質下性失語にはある一貫した 特徵があるということである。それは, 構音障害 か, あるいは失構音, ときには発声の問題など, ‘音’の問題が必発し, 理解障害, 喚語障害も大な り小なり認められるが，一方で，言語性短期記憶 は保たれ，また，音韻性錯語も目立たないことか ら, 復唱課題では高得点を得るという特徴である。 言語性短期記憶が保たれ, 文レベルでも復唱でき ることは超皮質性失語に類似するが，皮質下性失 語では ‘音’の問題が必発なので，超皮質性失語 とはいえない。また，“音”の問題は，その程度に は個人差があるが, 復唱時には軽減することも特 徵である。これは復唱のみでなく, 音読でも同様
の効果が得られることも報告されている。このよ うな特徵は他の失語型にはみられず, 特異性が高 い。

\section{3. 文レベルの障害}

文を理解するには，文の最後まで注意を持続す る把持力が必要である。これは言語性短期記憶 （音韻ループ）に相当する。その上で，文を構成す る語の位置づけ, 意味の理解・文法理解が必要に なる。したがって, 文理解障害には, 文法障害と ひとことでは括れないさまざまな問題にきめ細か く対応する必要がある。また, 発語で, 助詞を省 いているような発語は電文体と称されている。こ の原因のひとつとして, economy of output と解釈 されている現象がある。すなわち，しゃべりにく い状況では，できるだけ語を省略しようとする傾 向が起こるという解釈である。文法レベルの問題 ではなく, 発語の問題という解釈である。したが って, 本来の意味の文産生の問題は, このような 発語の問題に帰することができない部分に対して 考慮されなければならない。したがって, 電文体 イコール文法障害 (失文法) ではないことにも留 意しなければならない。

文レベルの障害にはさまざまなものがある。日 本語の文法で重要な助詞の正しい使い方, 文構造 の理解, 文の作成能力, 文の態変換能力などであ る。これらに関し，2 例の患者でその障害に二重 解離がみられたので報告する。患者 1 は 55 歳右利 き男性, 左島後部〜放線冠に梗塞巣があり, 患者 2 は 60 歳右利き女性, 左弁蓋部・尾状核〜放線冠 に梗塞巣がある。両者とも当初はブローカ失語だ ったが，その後，WAB 失語症検査のすべての項目 で $90 \%$ 超えるまでに回復した（図 $3(\mathrm{~A})$ )。こ の時点で残存していた障害はいずれも文レベルの 問題であった。そこで両者に(1)助詞の充填, (2)文 の正誤判断, (3)文作成, 文の態变換課題を検討し た。その結果, 患者 1では(1)助詞の充填, (3)文作 成・態変換に困難はなかったが, (2)文の正誤判断 に困難を示し, 一方, 患者 2 はその逆で, (1)助詞 の充填, (3)文作成・態変換に困難を呈したが, (2) 文の正誤判断に問題はなかった（図 $3(\mathrm{~A}))$ 。この 結果は助詞の充填・文作成や態変換能力と, 文の 正誤判断が少なくとも異なった神経基盤によって 


WAB (\%)
単語理解

図3（A）文に関する課題：患者1と2の比較

1. 助詞の充填課題：一般一文字仮名の穴埋めと 必ずペアで行う。

例A：けいたいでんわ（）はなす

B：けいたい（）んわではなす

* 28ペアABBAでランダムに施行。AとBで 正答率に有意差があった場合のみ助詞の 充填障害とする。

2. 文の正誤判断

例1. 私が電話に下さい/私も電話で下さい/私 は電話の下さい/私に電話を下さい/私を 電話が下さい の5つから正しい文を選 択する。

例2。明日，迎えに行きました/明日，迎えに 行きましょう/明日，迎えに行った/明日， 迎えに行かなかった/明日，迎えに行っ てしまった の5つから正しい文を選択 する。

3. 文作成課題

例：「朝」「散歩」「天気」を提示し，文を作成。

4. 態変換

例：「太郎は花子に花束を渡した」を「花子は〜」 で開始する文，「花束は〜」で開始する文 に変換。

担われている可能性を示唆する。文法に関係する 領域として，前頭葉の関与が指摘されているが, 今回の結果より, 弁蓋部と島後方で機能に差異が ある可能性が示された。弁蓋部に助詞の充填, 文 を作成・態を変換することに関与する機能があり， 島後方部にはその文の判断やそこに適切な内容を 充填することに関与する機能がある可能性が推測 された。前者は，たとえていえば，文という乗り 物（context）を作成し，後者はそこに乗せる内容 物（content）に関する機能と表現できるかもしれ ない。

\section{III. 言語の非言語性背景}

言語症状を理解するのに，言語の非言語性背景， すなわち言語機能を支えているさまざまな背景や 状況にも留意しなければならない。なぜならば, ヒトが使う言語は，言語それのみで一人歩きでき るものではないからである。

\section{1. 意図性と自動性の解離}

言語機能に，意図性と自動性の解離 (Alajuanine 1960）が昔から指摘されてきた。山鳥（1985）は “構え’の相違によって言語理解面でも変化が生じ ると述べている。この現象を復唱について，定量 的に検討したので報告する（Otsukiら 2005b，大 槻 2007b)。対象は典型的病巣 (左側頭葉〜頭頂葉) を持つ右利きウェルニッケ失語患者 9 名。全例, 単語レベルから復唱が不良であったが，絵の pointing 課題で，該当する絵を探しながら，思わ ず提示語を口ずさむことが少なからずみられた。 そこで，患者には復唱を意識したり，強制したり しないよう留意しながら, 復唱すると理解しやす いかもしれない旨を伝えた上で, 単語理解の pointing 課題を装って (disguised task), 正しく復 唱した単語数を計上した。その後, 同じ単語群を 今度は復唱課題であることを明確にし, 復唱成績 として計上した（これを ABBA 法で行った）。disguised task は，患者の無意識な発語を計上するの みなので，無反応も多く，正しい語再生は当然少 ないことが予想されたが，結果は，それでもなお disguised taskのほうが，復唱課題として施行した 場合よりも有意に多く復唱できていた（図3(B))。 この結果は復唱能力においても意図性と自動性の 解離があることを定量的に示している。

\section{2. 順序の効果}

語理解に関して，始めの言葉が理解しやすい （山鳥 1985）ことも指摘されていた。今回は，呼 称に関してこの効果を検討した。脳梗塞による右 利き失語症例 11 名（3 例のウェルニッケ失語, 8 例の超皮質性感覚失語患者）に呼称課題を施行し た。これは，3単語を 1 単位とし，各単位ごとに 単語のカテゴリーを変えた。たとえば，犬，牛， 


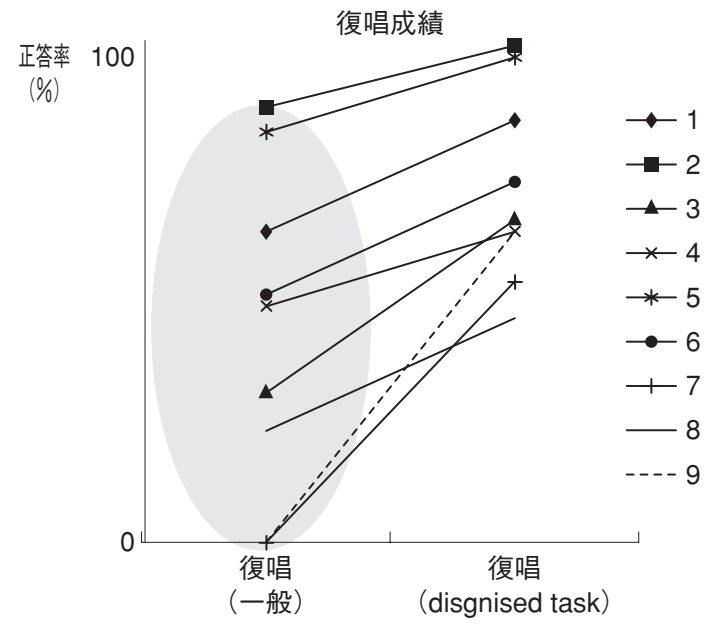

図3（B）復唱課題とdisguised taskの比較 (1)復唱課題：単語を復唱する (40個の単語)。

(2)disguised task：単語を聞いて, 該当する線描画を探させ る（10択）(検查者はその復唱した単語数を数える）。

*(2)では10択であるが, 該当する線描画は全体の $20 \%$ しか ない(絵を見てその呼称をする可能性を減らすため)。

* (2)で, 被験者に理解を深めるために復唱することを推奖 する旨を伝えるが，それを評価の対象にすることは伝え ない。

* (2)の評価は，無反応，音韻性錯語などは「誤り」とし， 正しい復唱単語が発せられた場合のみをカウントする。

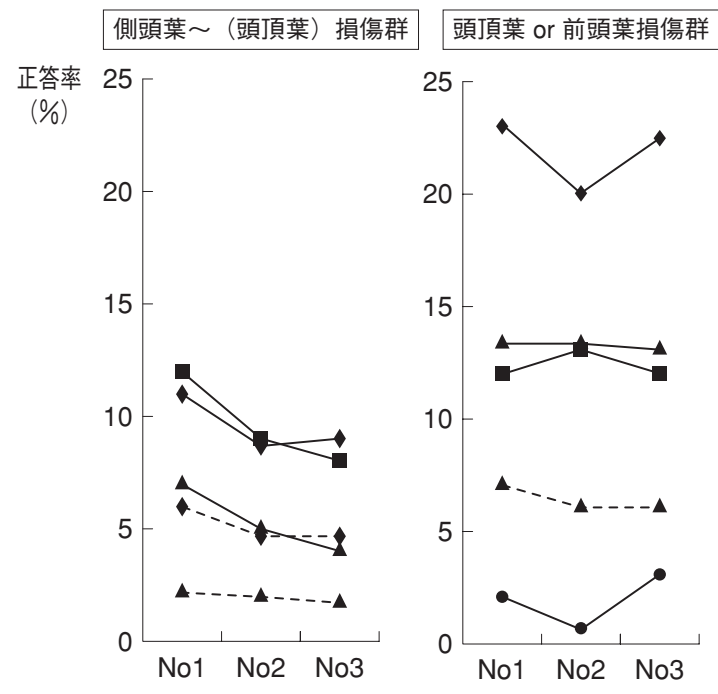

図3（C）順序の効果の検討

馬の 3 語が続いたのち，筆，鉛筆，万年筆と続く。 ここで，犬や筆は，各カテゴリーの冒頭語として No1 群，牛，鉛筆は No2 群，馬，万年筆は No3 群
とする。No1群, No2 群, No3 群ごとに正解を集 計した $(\mathrm{n}=60$, また, No1〜3の単語はすべて 入れ替えて 3 度施行し, 正答率を算出した)。結果 （図 $3(\mathrm{C})$ ）は，側頭葉に病巣が及んでいた 5 例は No1 群の正答率が高く, 前頭葉や頭頂葉に病巣が 限局していた 6 例はその傾向が明らかではなかっ た。この結果より, 呼称においても最初の課題が 良好であるという順序の効果が認められることが 明らかになったが，この効果は側頭葉損傷群にと くに当てはまる現象である可能性が示唆された。 したがって，この現象は病巣によって異なる可能 性を考慮しながら検討されるべきことが示唆され た。

\section{3. 最大限の呼称能力を引き出す試み}

脳梗塞による左前頭葉損傷患者で, 呼称能力を 引き出す試みを行った。患者は 69 歳右利き男性。 復唱は可能だが, 喚語障害が重度で, 線描画の呼 称は $5 / 50$ だった。この患者に，交互呼称を試みた。 これは筆者が純粋失読患者に用いた方法の応用で (大㭇 2008e), 左半球に負荷がかかる課題を続け ると，保続やその他の誤りが増加することから， 右半球を活性化すると考えられる課題を干渉とし て交互にはさみ, 左脳の “構え” を遂次解く（と 推測される）方法である。本患者には, 線描画の 呼称と, 環境音を聴いて該当する対象を絵カード から選択する課題を交互に行った（環境音を聴い ての指示 $100 \%$ であることは確認済)。結果は, 交 互呼称で呼称成績が向上した（図 4)。誤り内容は, 保続が減り，語性錯語の割合が増えていた。この ことは, 左右脳の交互使用によって, 保続の影響 を減らし, 類似意味へのアクセスを増やせる可能 性を示唆する。

\section{おわりに}

失語症はいまだ多くの謎につつまれている。私 たちができることは，常に“脳”に問いかけ，働 きかけることである。そうしたら，“脳”はきっと 何かヒントを与えてくれるに違いない。

追記：本シンポジウムは在天の田邊先生に捧げ る。シンポジウムのお話をいただいた時, 田邊先 生のおっしゃった言葉が耳から離れない。「失語症 

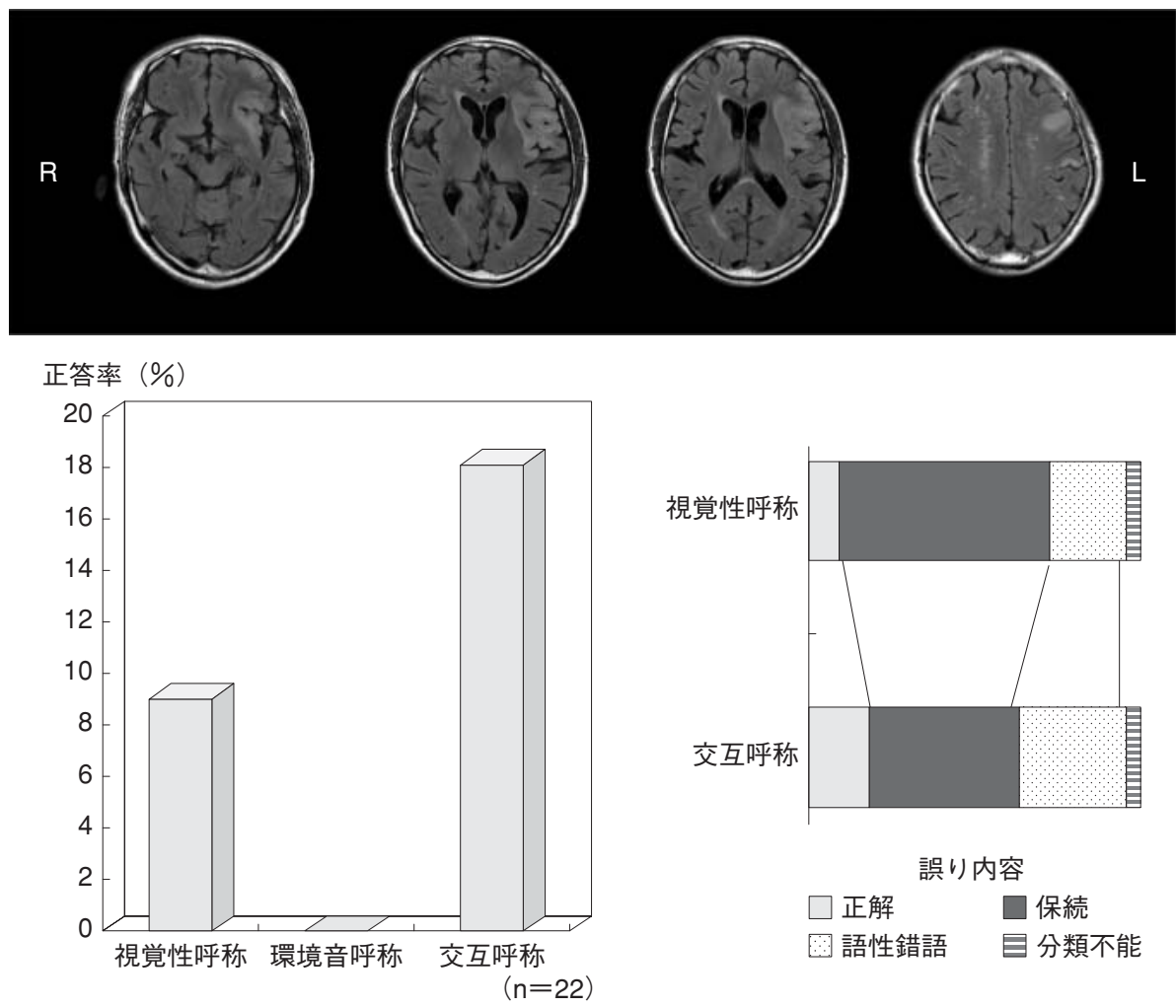

図4

上段：MRI

下段左：視覚性呼称, 環境音呼称, 交互呼称の比較

下段右：視覚性呼称と交互呼称の誤り内容の比較

をみるのに, 何が一番大事か, 忘れられている。 一番大事なことを若い人たちに伝えなあかん」と。 “一番大事なこと'‥それを問い続けていくことが, 田邊先生の薰陶を受けることができた私たちがで きる唯一のことなのかもしれないと思う。

\section{文献}

1) Alajouanine, T. h. : Ballager and Jackson ; The principle of Ballarger-Jackson in aphasia. JNNP, 23 : 191-193, 1960.

2 ) Alexander, M. P., Benson, D. F. \& Stuss, D. T. : Frontal lobes and language. Brain and Lang., 37 : 656-691, 1989.

3 ) Baddeley, A. D. \& Hitch, G. : Working memory.
The psychology of Learning and Motivation ; Advances in Research and Theory. Academic Press, New York, 1974, pp. 47-89.

4 ) Benson, D. F. : Fluency in aphasia ; Correletion with radioisotope scan localization. Cortex, 3 : 373-394, 1967.

5 ) Benson, D. F. : Aphasia, alexia, and agraphia. Churchhill Livingstone, USA, 1979.

6 ) Benson, D. F. : Aphasia. In : Clinical Neuropsychology (eds Heilman, K. M. \& Valenstein, E.) . 3rd Ed., Oxford University Press, 1993.

7 ) Della Sala, S. \& Logie, R. H. : When working memory does not work ; the role of working memory in neuropsychology. Handbook of Neuropsuychology vol. 8 (eds Boller, F., et al.) . 
Elsevier Science Publishers BV, Amsterdom 1993.

8 ) 榎戸秀昭：超皮質性運動失語. 精神医学, 27： $671-677,1985$.

9 ）榎戸秀昭, 鳥居方策, 鈴木重忠, ほか：前方失 語とローランド動脈. 神経心理学, 4：125-132, 1988.

10) Freedman, M. : Anatomic basis of transcortical motor aphasia. Neurology, 34 : 409-417, 1984.

11）濱中淑彦, 波多野和夫, 石黒聖子, ほか：前頭 葉と失語一超皮質性感覚失語像をめぐって一. 失語症研究, $12 ： 130-144,1992$.

12) Goodglass, H., Quafasel, F. A. \& Timberlake, W. H. : Phrase length and the type and severity of aphasia. Cortex, 1 : 133-720, 1964.

13) Green, E. \& Howes, D. H. : The nature of conduction aphasia ; a study of anatomic and clinical features and of underlying mechanisms. In : Studies in neurolongustics vol. 3 (eds Ehiteaker, H. \& Whiteaker, H. A.) . Academic Press, New York, 1977, pp. 123-156.

14) 河村満, 塩田純一, 平山恵造：神経学 （Neurology）の立場からみた構音障害一特に Broca 野周辺病巣における構音の異常について 一. 音声言語医学, $31 ： 235-241,1990$.

15) Lecours, A. R. \& Lhermitte, F. : The "pure form" of the phonetic disintegration syndrome (pure anarthria) ; Anatomo-clinical report of a historical case. Brain and Lang., 3 : 88-113, 1976.

16）松田実, 鈴木則夫, 長浜康弘, ほか：純粋語 喂は中心前回症候群である；10 例の神経放射線 学的·症候学的分析. 神経心理学, 21：183190, 2005.

17) McCarthy, R. A. \& Warrington, E. K. : A two orute model of speech production ; Evidence from aphasia. Brain, 197 : 463-485, 1984.

18）水田秀子：言語性短期記憶障害の一例。失語症 研究, $9 ： 146-153,1999$.

19) Mori, E., Yamadori, A. \& Furumoto, M. : Left precentral gyrus and Beoca's aphasia ; A clinico- pathological study. Neurology, 39 : 51-54, 1989.

20）大㭇美佳, 相馬芳明, 小山 晃, ほか：左前頭 葉病変による超皮質性感覚失語の 1 例. 脳と神経, 46 : 866-871, 1994.

21）大㭇美佳, 相馬芳明, 小野寺理, ほか：左前頭 葉内側面損傷による超皮質性運動失語における 超理解。脳と神経, 47：1081-1085, 1995.

22) Otsuki, M., Soma, Y., Koyama, A., et al. : Nahoko Yoshimura, Hiroko Furukawa, Shoji Tsuji Transcortical sensory aphasia following left frontal lesion. J. Neurol., 245 : 69-76, 1998.

23）大槻美佳, 相馬芳明 : 短期記憶. 臨床精神医学 講座 記憶の臨床. 中山書店, 東京, 1999a, pp. 49-60.

24）大槻美佳, 相馬芳明：局在病変による錯語。失 語症研究, $19 ： 182-192,1999 b$.

25）大槻美佳：錯語の脳内メカニズム。神経研究の 進歩, 47 : 725-733, 2003.

26）大柣美佳：Anarthrieの症候学. 神経心理学, $21: 172-182,2005 a$.

27) Otsuki, M., Soma, Y., Yoshimura, N. et al. : How to improve repetition ability in patients with Wernicke's aphasia ; the effect of disguised task. JNNP, 76 : 733-735, 2005b.

28）大槻美佳：言語機能の局在地困. 高次脳機能研 究, $27: 231-243,2007 a$.

29）大㭇美佳：脳のしくみと言葉のしくみ. 臨床神 経心理, $18: 1-18,2007 b$.

30）大柣美佳：失語症の定義とタイプ分類. 神経内 科, $68: 155-165,2008$ a.

31）大㭇美佳：言語野の神経学. 神経内科, $68 ： 166$ $-173,2008 b$.

32) 大槻美佳, 相馬芳明：伝導失語。神経内科, 68 : 208-214, 2008c.

33）大槻美佳：失語症の診療一最近の進歩一. 臨床 神経学, 48：853-856,2008d.

34）大槻美佳：視覚失認からみた純粋失読。神経心 理学, $24: 136-145,2008 \mathrm{e}$.

35) Rubens, A. B. : Transcortical motor aphasia. In : 
Studies in Neurolingustice vol. 1 (eds Whiteaker, H. \& Whiteaker, H. A.) . Academic press, New York, 1976, pp. 294-303.

36) Saffran, E. M. \& Martin, O. S. M. : Immediate memory for word lists and sentences in a patient with different short-term memory. Brain and Lang., 2 : 420-433, 1975.

37) Sakurai, Y., Takeuchi, S., Kojima, E., et al. : Mechanism of short-term memory and repetition in conduction aphasia and related cognitive disorders ; A neuropsychological and neuroimaging study. J. Neurol. Sci., 154 ： 182-193, 1998.

38）櫻井靖久：伝導失語の病像と病巣. Annual Review 神経 2001. 中外医学社, 東京, 2001, pp. 287-294.

39）佐藤睦子, 後藤恒夫, 渡辺一夫：左前頭葉損傷 により超皮質性感覚失語と同語反復症を呈した 1 例. 神経心理学, $7: 202-208,1991$.

40) 相馬芳明：伝導失語と短期記憶. 神経心理学, $2: 21-30,1986$.

41）相馬芳明：伝導失語と短期記憶 (STM). 失語症 研究, $12 ： 145-152,1992$.
42）相馬芳明：音韻性（構音性）ループの神経基盤. 失語症研究, $17 ： 149-154,1997$.

43）杉下守弘：WAB 失語症検査（日本語版）。医学 書院, 東京, 1986.

44）杉下守弘：発語失行. 失語症研究, 129：33-37, 1994.

45）田邊敬貴, 大東祥孝：Broca 領野と Broca 失語. 脳と神経，34：797-804, 1982.

46) Tonkonogy, J. \& Goodgrass, H. : Language function, foot of third frontal gyrus, and rolandic operculum. Arch. Neurol., 38 : 486-490, 1981.

47) Vallar, G. \& Papagno, C. : Neuropsychological impairments of short-term memory. Handbook of Memory Disorders (eds Baddeley, A. D., et al.) . John Wiley \& Sons, Chichester, 1995, pp. 135-165.

48) Warrington, E. K., Logue, V. \& Pratt, R. T. C. : The anatomical localization of selective impairment of auditory verbal short-term memory. Neuropsychologia, 9 : 377-387, 1971.

49) 山鳥 重: 神経心理学入門. 医学書院, 東京, 1985. 


\section{Abstract}

\section{Aphasia}

\section{Mika Otsuki*}

For understanding aphasia, I proposed a simple procedures and the point of view. First, we should divide brain function related language into two systems : one is the phonetic \& phonemic system and the other is the content \& context system. These systems also correspond to definite anatomical localization. Second, in terms of estimating speech output, I pointed out that it is simpler and more rational to adopt anarthria as a standard than using traditional fluent/non-fluent dichotomy because anarthria is an established focal sign of an impairment of the left precentral gyrus. Regarding estimating repetition ability, there is no clear standard to delineate between good and poor of repetition ability. Then it is helpful to estimate phonemic paraphasia and verbal short term memory, both of which are implicated in the anatomical localization. In addition I referred localization of four elementary impairments of language and implications in the classical aphasic terminology. With respect to aphasic terminology, there still remains many problems to be solved. I referred some of them, for example ; where to place transcortical motor aphasia, characteristics of subcortical aphasia, and sentence processing impairment. I also elucidated the influence of non linguistic background upon language ability : repetition ability which shows automatico- voluntary dissociation in Wernicke's apahsics, first order effect of naming ability in the aphasic patients with temporal lobe damages, how to improve naming ability in an aphasic patient using alternative tasks.

\footnotetext{
* School of Psychological Sciences, Health Sciences University of Hokkaido.

2-5 Ainosato, Kita-ku, Sapporo-shi, Hokkaido 002-8072, Japan
} 